\title{
VARIAN IKAN NIKE (Awaous melanocephalus) DAN IKAN CAKALANG (Katsuwonus pelamis) TERHADAP MUTU KERUPUK
}

\author{
Desi Arisanti \\ Program Studi Teknologi Hasil Pertanian, Politeknik Gorontalo \\ JL.Muklis Rahim, kec Botupingge kab Bone Bolango Prov Gorontalo,Indonesia \\ Email: desiarisanti@poligon.ac.id
}

\begin{abstract}
the current utilization of nike fish and tuna is still limited to fresh condition. Crackers are a very popular food by all levels of society. Utilization of nike fish and tuna in processed form with longer shelf life has not been done. Nutritional content of both types of fish is a reason in the selection as a basic ingredient in making crackers. The purpose of this research is to know the formulation of nike fish and tuna to the quality of crackers. The observation parameters in this study are the level of favorite or hedonic method, water content, ash content, bloom and texture analizer. The results showed that the average water content of nike fish crackers and skipjack fish from treatment A1 3.3\%, treatment A2 3.29\%, A3 3.77\%. Mean of ash content at treatment of A1 1,97\%, treatment of A2 1,55\%, treatment of A3 1,58\%. The average of A1 is $283,54 \%$, A2 242,75\%, A3 182,23\%. and the mean of analyzer analyzer test at A1 1185,6\%, A2 708,9\%, and A3 783,83\%. Based on the results and the discussion that has been done on the quality of crackers, it can be concluded that the best formula and liked by the panelists is formula A1
\end{abstract}

Key words : Crackers,nike fish, tuna fish

\section{PENDAHULUAN}

Kerupuk merupakan makanan yang sangat digemari oleh semua lapisan masyarakat. Secara kuantitatif belum ada data yang menggambarkan jumlah konsumsi kerupuk ikan. Meskipun demikian dapat diperkirakan bahwa jumlah konsumsi kerupuk relatif tinggi, karena makanan olahan ini banyak digemari oleh masyarakat luas. Kerupuk merupakan produk pangan bersifat kering dan ringan yang biasanya terbuat dari bahan dasar udang. Alternatif lain yang dapat dijadikan sebagai bahan dasar pembuatan kerupuk adalah ikan nike. Ikan nike memiliki kadar air $79,76 \%$, protein $16,89 \%$, karbohidrat 0,30\%, dan lemak 0,76\%. Berdasarkan komposisi tersebut dapat dikatakan bahwa ikan nike memiliki kadar air yang cukup tinggi, dengan kandungan protein sedang, dan lemak rendah. Selain itu, ikan nike juga mengandung asam amino essensial seperti leusin $1,153 \%$, dan lisin $0,843 \%$, juga mengandung asam dokosaheksanoat (DHA) $14,81 \%$, asam oleat $8,50 \%$, dan asam eikosapentanonoat (EPA) 2,22\%. Selain itu juga mengandung mineral magnesium dan kalsium yang tinggi.

Di daerah Gorontalo pemanfaatan ikan nike masih terbatas pada kondisi segar ataupun hanya dikeringkan tanpa ada pengolahan lebih lanjut. Beberapa pemanfaatan ikan nike adalah dibuat perkedel, tumis, dan pepes. Pemanfaatan ikan nike dalam bentuk olahan dengan daya simpan yang lebih lama belum dilakukan. Selain ikan nike, ada juga jenis ikan lain yang dapat dijadikan bahan baku dalam pembuatan kerupuk yaitu ikan cakalang.

Ikan Cakalang (Katsuwonus pelamis) adalah jenis ikan laut yang biasa dikonsumsi oleh masyarakat Indonesia dan memiliki kandungan protein tinggi yang baik untuk tubuh manusia sehingga ikan cakalang tergolong sumber daya 
perikanan pelagis penting dan merupakan salah satu komoditi ekspor non-migas (Kekenusa $d k k$., 2012). Ikan cakalang terdapat hampir di seluruh perairan Indonesia, terutama di Gorontalo. Ikan cakalang merupakan salah satu komoditi perikanan yang menjadi primadona.

Kandungan gizi dari kedua jenis ikan tersebut menjadi alasan dalam pemilihan sebagai bahan dasar dalam pembuatan kerupuk. Oleh sebab itu, dalam pembuatan kerupuk dilakukan beberapa perbandingan antara ikan nike dengan ikan cakalang untuk membuat mutu kerupuk yang lebih baik. Penelitian ini dilakukan untuk mengetahui formulasi ikan nike dan ikan cakalang terhadap mutu kerupuk seperti kerupuk yang biasa dikonsumsi oleh masyarakat.

\section{METODE PENELITIAN}

\subsection{Waktu dan Tempat}

Penelitian ini dilaksanakan pada bulan April sampai bulan Mei 2017 di Laboratorium Teknologi Hasil Pertanian, Politeknik Gorontalo.

\subsection{Alat dan Bahan}

2.2.1.

\section{Alat}

Alat yang digunakan dalam pembuatan kerupuk adalah oven, timbangan, wadah, plastik, pisau, talenan, sendok, dan penggiling daging. Alat untuk analisa, yaitu glass ware, cawan petridish/porselin, desikator, timbangan, tanur, nitrogen determination, degastion, buret, scruber, pipet morh, dan labu kjeldahl.

\subsubsection{Bahan}

Adapun bahan yang digunakan dalam pembuatan kerupuk adalah : ikan nike, ikan cakalang, tepung tapioka, garam, bawang putih dan minyak goreng. Bahan analisa $\mathrm{H}_{2} \mathrm{SO}_{4}, \mathrm{NaOH}, \mathrm{HCl}$, tablet Kjeldahl, indikator PP dan akuades.

\subsection{Prosedur Kerja (Modifikasi Tababaka,} 2004)

1. Dicampurkan ikan nike dan ikan cakalang sesuai perlakuan :

A1 = Ikan nike $100 \mathrm{~g}: 100 \mathrm{~g}$ ikan cakalang

A2 = Ikan nike $150 \mathrm{~g}: 50 \mathrm{~g}$ ikan cakalang

A3 = Ikan nike $50 \mathrm{~g}: 150 \mathrm{~g}$ ikan cakalang

2. Ditambahkan tepung tapioka $300 \mathrm{~g}$, garam 10 $\mathrm{g}$, bawang putih $20 \mathrm{~g}$ dan air $200 \mathrm{~mL}$.

3. Diaduk adonan sampai kalis.

4. Dikukus adonan pada suhu $\pm 100{ }^{\circ} \mathrm{C}$ selama 2 jam

5. Didinginkan dalam refrigerator selama 18 jam

6. Diiris adonan dengan ketebalan 2 sampai $3 \mathrm{~cm}$.

7. Keringkan menggunakan oven pada suhu 80 ${ }^{\circ} \mathrm{C}$ selama 3 jam.

8. Digoreng irisan kerupuk mentah pada suhu $\pm 170{ }^{\circ} \mathrm{C}$ selama 30 detik (sambil dibolakbalik).

9. Kerupuk siap dikonsumsi.

\section{HASIL DAN PEMBAHASAN}

\subsection{Tingkat kesukaan Peningkatan Mutu Kerupuk dengan Penambahan Ikan Nike dan Ikan Cakalang}

Untuk melihat produk yang paling diminati atau disukai oleh panelis pada penelitian ini ditentukan melalui uji organoleptik. Penilaian yang dilakukan melalui empat parameter yaitu warna, aroma, rasa, tekstur.

\subsection{Warna}

Menurut Winarno (2008), secara visual faktor warna tampil lebih dahulu dan kadangkadang sangat menentukan. Warna juga merupakan salah satu parameter yang di gunakan konsumen dalam memilih produk.

Nilai sensori tingkat kesukaan warna dari peningkatan mutu kerupuk dengan penambahan 
ikan nike dan ikan cakalang dapat dilihat pada Gambar 1.

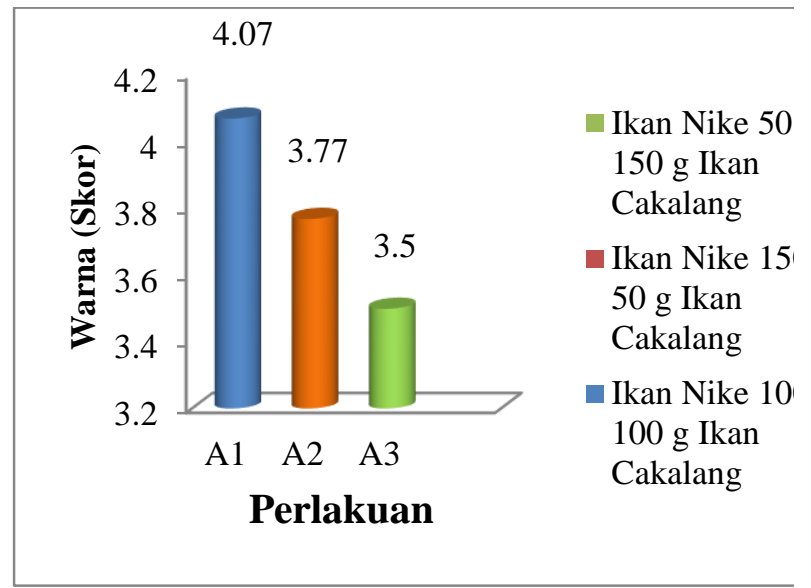

Gambar 1. Hasil uji organoleptik terhadap warna kerupuk

Menurut Winarno (2002), penentuan mutu bahan pangan pada umumnya sangat bergantung pada beberapa faktor, diantaranya cita rasa, warna, tekstur dan nilai gizinya. Selain itu ada faktor lainnya misalnya sifat mikkrobiologis.

Berdasarkan hasil uji organoleptik, warna dari 3 formulasi Peningkatan mutu kerupuk dengan penambahan ikan nike dan ikan cakalang berada pada kisaran 3,5 -4,93 artinya pada kisaran ini memasuki taraf kesukaan. Kerupuk dengan perbandingan ikan nike dan ikan cakalang pada perlakuan A1 menghasilkan warna yang agak di sukai sampai di sukai $(4,07)$ oleh panelis, sedangkan perlakuan A2 (3,77), dan A3 menghasilkan warna yang netral/biasa dengan nilai $(3,5)$ oleh panelis.

Dilihat dari Gambar 1 diatas, rata-rata para panelis menyukai perbandingan warna kerupuk antara ikan nike dan ikan cakalang. Formulasi A1 merupakan formulasi yang warnanya paling di sukai oleh panelis. Hal ini disebabkan karena perbandingan antara ikan nike dan ikan cakalang adalah sama yaitu 100 g : 100 g. Sehingga menghasilkan warna putih pada kerupuk.

\subsection{Aroma}

Menurut Winarno (2008), aroma makanan umumnya menentukan kelezatan bahan makanan dan banyak berhubungan dengan indra penciuman. Senyawa beraroma sampai ke jaringan penciuman yang berada didalam lubang hidung bersama-sama dengan udara. Pada umumnya bau yang diterima oleh hidung dan otak lebih banyak mengandung ramuan atau campuran yang terdiri atas empat bau utama yaitu : harum, asam, tengik, dan hangus. Penciuman biasanya disebut juga sebagai penyicipan jarak jauh untuk mengenal enak tidaknya suatu makanan yang belum terlihat. Di dunia industri pengolahan makanan, peranan aroma sangatlah penting dalam menentukan suatu makanan yang disukai atau tidak disukai oleh panelis.

Nilai sensori tingkat kesukaan aroma dari peningkatan mutu kerupuk dengan penambahan ikan nike dan ikan cakalang dapat dilihat pada Gambar 2.

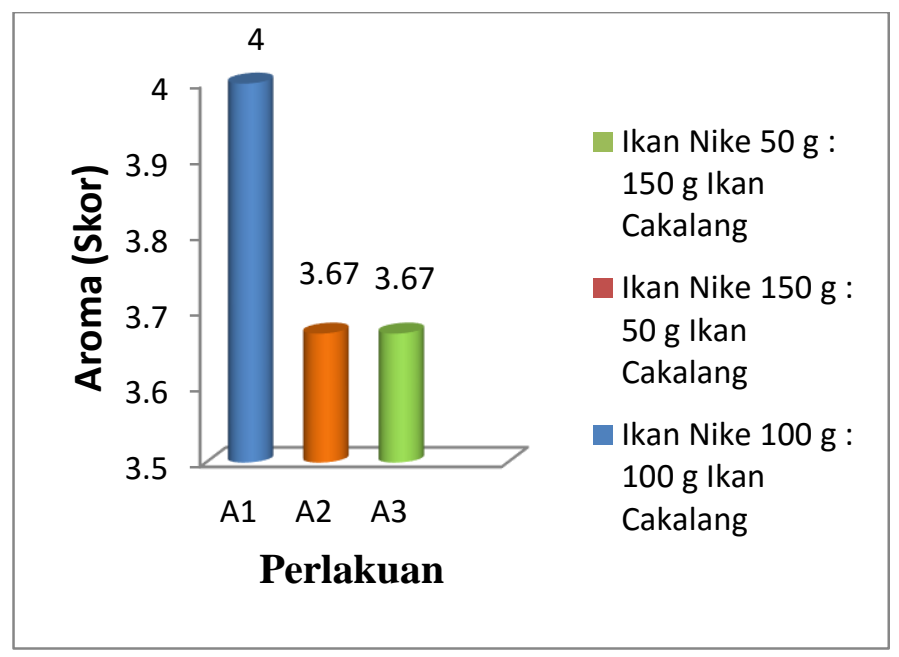

Gambar 5. Hasil uji organoleptik terhadap aroma kerupuk

Berdasarkan Gambar 2 diatas, nilai ratarata tingkat kesukaan dari aroma kerupuk ikan nike dan ikan cakalang yaitu berkisar antara 3,67 - 4 yaitu antara netral sampai suka. Dari ketiga formula ini A1 adalah yang paling banyak di sukai oleh para panelis. Sedangkan A2 dan A3 sama nilai tingkat kesukaan aromanya. Hal ini membuktikan bahwa sampel A1 memiliki bau khas karena memiliki nilai 
perbandingan yang sama sehingga aroma ikan nike dan ikan cakalang dapat di imbangi. Sedangkan A2 dan A3 memiliki nilai yang sama, artinya perlakuan A2 dan A3 memilki aroma yang tidak terlalu khas, hal ini disebabkan aroma nike yang terlalu menyengat ataupun ikan cakalang.

\subsection{Rasa}

Menurut Winarno (2008), rasa adalah penilaian indrawi yang menggunakan indra pengecap atau lidah. Rasa juga merupakan salah satu faktor mutu faktor mutu yang mempengaruhi suatu produk pangan. Penginderaan cicipan atau rasa dapat di bagi menjadi empat cicipan utama yaitu : asin, asam, manis, dan pahit. Bumbu yang ditambahkan akan memberikan keseimbangan fungsional pada proses pengolahan bahan makanan. Adanya interaksi komponen rasa lain dengan komponen utama rasa primer ini dapat meningkatkan intensitas rasa atau menurunkan intensitas rasa.

Menurut Erawati (2001), rasa merupakan parameter yang sangat penting dalam menentukan tingkat penerimaan konsumen terhadap suatu produk makanan. Rasa yang enak dapat menunjang produk sehingga diterima oleh konsumen. Nilai sensori tingkat kesukaan rasa dari peningkatan mutu kerupuk penambahan ikan nike dan ikan cakalang dapat dilihat pada Gambar 3.

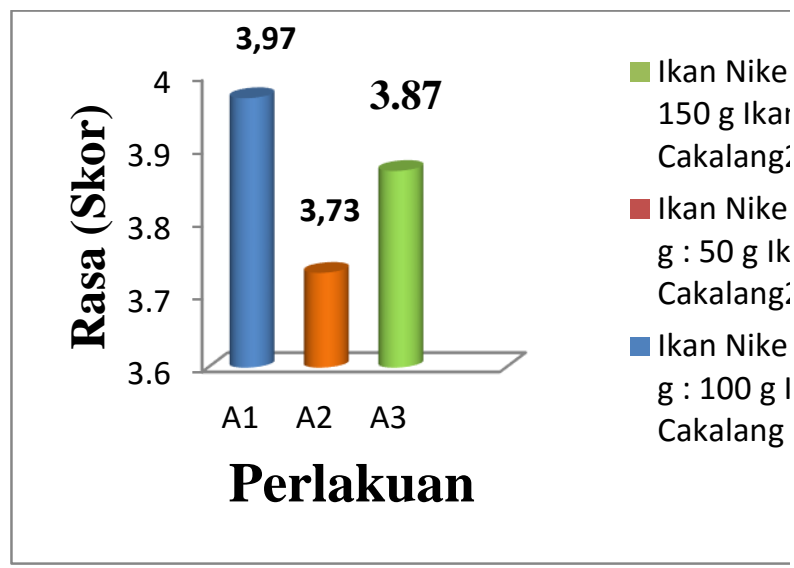

Gambar 3. Hasil uji organoleptik terhadap rasa kerupuk dengan perbandingan ikan nike dan ikan cakalang.

Berdasarkan hasil uji organoleptik terhadap rasa kerupuk dengan perbandingan ikan nike dan ikan cakalang bahwa tingkat penerimaan panelis rata-rata 3,37-3,97 pada taraf netral sampai suka. Kerupuk perbandingan ikan nike dengan ikan cakalang terdiri atas perlakuan A1, A2 dan A3. Pada perlakuan A2 yang paling sedikit disukai oleh para panelis. Hal ini disebabkan karena perbandingan ikan nike dan ikan cakalang, yang lebih banyak penambahannya adalah ikan nike. Sedangkan yang paling banyak disukai oleh para panelis adalah perlakuan A1. Hal ini disebabkan karena penambahan ikan nike dan ikan cakalang yang perbandingannya sama yaitu $100 \mathrm{~g}$ : $100 \mathrm{~g}$, sehingga menghasilkan rasa yang khas pada kerupuk.

\subsection{Tekstur}

Menurut Dewi Kusuma dalam Panti mukmin (2014), setiap makanan mempunyai sifat tekstur tersendiri tergantung keadaan fisik, ukuran, dan bentuknya. Penilaian terhadap tekstur dapat berupa kekerasan, elastisitas, kerenyahan, kelengketan, dan sebagainya. Tekstur merupakan bagian penting dari mutu rasa. Tekstur produk pangan merupakan salah satu komponen yang dinilai dalam uji organoleptik. Adapun nilai sensori tingkat kesukaan tekstur dari peningkatan mutu kerupuk penambahan ikan nike dan ikan cakalang dapat dilihat pada Gambar 4. 


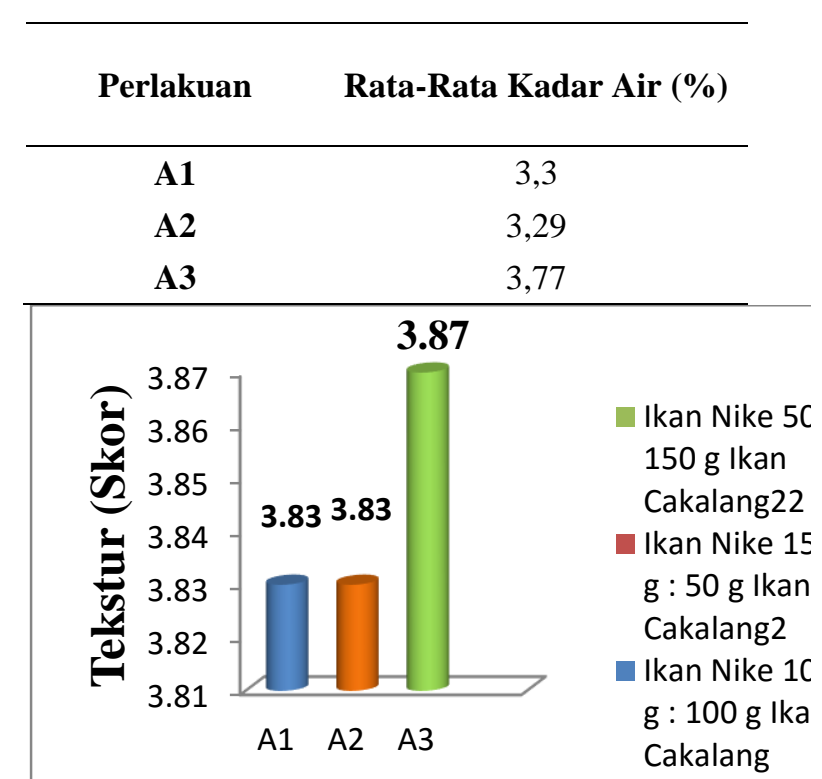

Perlakuan

Gambar 4. Hasil uji organoleptik terhadap tekstur kerupuk dengan perbandingan ikan nike dan ikan cakalang.

Dari Gambar di atas, dapat dilihat bahwa tingkat kesukaan dari tekstur kerupuk ikan nike dan ikan cakalang berkisar di antara 3,83 - 3,87 yaitu pada tingkat biasa/netral. Berdasarkan hasil uji organoleptik, panelis lebih menyukai formulasi A3. Hal ini dipengaruhi oleh penambahan ikan cakalang yang digunakan, dan penambahan tepung tapioka yang memiliki kandungan amilopektin yang cukup tinggi sehingga tekstur yang dihasilkan sangat renyah.

Menurut Muliawan (1991), salah satu parameter mutu kerupuk goreng adalah volume pengembangan. Volume pengembangan dipengaruhi oleh kadar air kerupuk mentah dan suhu penggorengan. Makin banyak penambahan bahan pati, makin kecil pengembangan kerupuk pada saat penggorengan.

\subsection{Analisa Sifat Kimia}

\subsubsection{Hasil Kadar Air Kerupuk Ikan Nike dan Ikan Cakalang.}

Menurut Erawati (2001), Air merupakan komponen penting dalam bahan makanan yang dapat mempengaruhi kenampakan, tekstur dan cita rasa makanan. Hasil analisa dari ketiga perlakuan dengan tiga kali ulangan, ditunjukkan oleh Tabel 1 dan Gambar 5 dibawah ini.

Tabel 1. Nilai rata-rata kadar air kerupuk dengan penambahan ikan nike dan ikan cakalang.

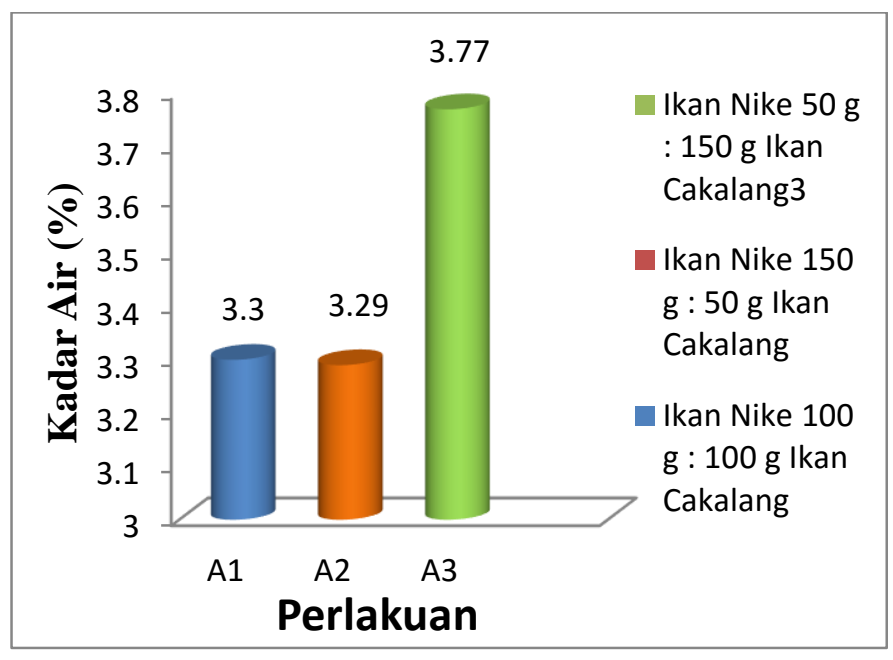

Gambar 5. Rata - Rata kadar air kerupuk

Berdasarkan analisis sidik ragam kadar air (Lampiran 5) bahwa F hitung $(0,78)$ lebih kecil dari F tabel $(0,05)$ yaitu 5,14 dan F tabel $(0,01) 10,92$. Hasil analisa sidik ragam ini menunjukkan bahwa kombinasi antara ikan nike dan ikan cakalang tidak berpengaruh nyata terhadap kadar air kerupuk, sehingga tidak dilakukan uji BNT lagi.

Berdasarkan dari hasil Tabel 1 di atas, dapat dilihat bahwa rata-rata kadar air kerupuk pada perlakuan A3, memberikan hasil kadar air yang tertinggi sedangkan rata-rata kadar air yang terrendah adalah perlakuan A1 dan A2. Perlakuan A1 dan A2 tidak terlalu jauh berbeda nilai rataratanya, perbedaanya hanya $1 \%$ dari kedua sampel tersebut. Hal ini disebabkan pada perlakuan A3 banyak mengandung kadar air yang sangat tinggi dibandingkan dengan perlakuan A1 dan A2. Hal ini menunjukkan kadar air yang dihasilkan oleh kerupuk dengan penambahan ikan nike dan ikan cakalang memenuhi standar SNI 1999. Semakin rendah kandungan air suatu bahan, maka tingkat 
kerusakannya semakin rendah dan semakin tinggi kadar air suatu bahan semakin cepat, tingkat kerusakan bahan itu sendiri. Kerenyahan kerupuk ikan sangat ditentukan tingkat kadar airnya. Semakin banyak mengandung air, maka kerenyahannya akan semakin berkurang (Wahyono dan Marzuki, 1996).

Menurut Muliawan (1991), kadar air yang terikat pada kerupuk sebelum digoreng sangat menentukan volume pengembangan kerupuk matang. Jumlah uap air yang terdapat dalam bahan pangan ditentukan oleh lamanya pengeringan, suhu penggorengan, kecepatan aliran udara, kondisi bahan dan cara penumpukan serta penambahan air sewaktu pembuatan adonan.

\subsubsection{Hasil Kadar Abu Kerupuk Ikan Nike dan Ikan Cakalang.}

Kadar abu merupakan zat organik sisa suatu pembakaran zat organik dalam bahan pangan. Bahan pangan terdiri dari $96 \%$ bahan organik dan air,, sedangkan sisanya merupakan unsur-unsur mineral. Penentuan kadar abu dapat di tentukan dengan tujuan, antara lain untuk menentukan baik atau tidaknya suatu pengolahan, mengetahui jenis bahan yang digunakan dan sebagai penentu nilai gizi suatu bahan makanan.

Hasil analisa rata-rata kadar abu kerupuk ikan nike dan ikan cakalang dari ketiga perlakuan dengan tiga kali ulangan, ditunjukkan oleh Tabel 6 dan Gambar 9 di bawah ini.

\section{Perlakuan Rata-Rata Kadar Abu (\%)}

\begin{tabular}{ll}
\hline $\mathbf{A 1}$ & 1,97 \\
$\mathbf{A 2}$ & 1,55 \\
$\mathbf{A 3}$ & 1,58 \\
\hline
\end{tabular}

Tabel 6. Nilai rata-rata kadar abu kerupuk dengan penambahan ikan nike dan ikan cakalang.

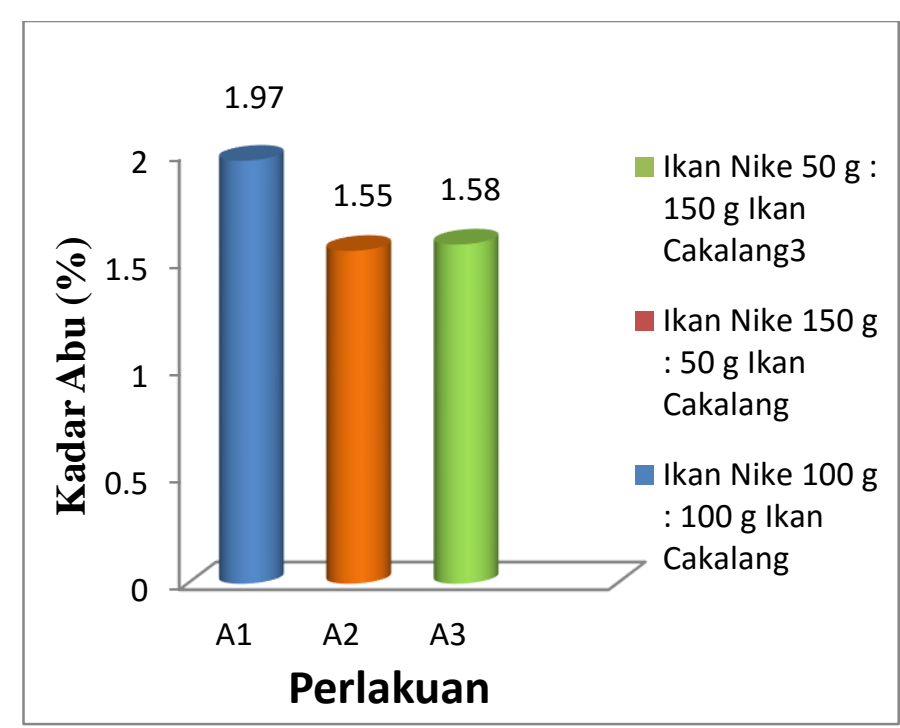

Gambar 6. Rata - Rata kadar abu kerupuk ikan nike dan ikan cakalang.

Berdasarkan Gambar 6 di atas, nilai ratarata kadar abu kerupuk dengan penambahan ikan nike dan ikan cakalang berkisar antara 1,55\% 197\%. Dari hasil analisis sidik ragam kadar abu (Lampiran 6) bahwa F hitung (2,50) lebih kecil dari F tabel $(0,05)$ yaitu 5,14 dan F tabel $(0,01) 10,92$. Hasil analisa sidik ragam ini menunjukkan bahwa kombinasi antara, ikan nike dan ikan cakalang tidak berpengaruh nyata terhadap kadar abu kerupuk, sehingga tidak dilakukan uji BNT lagi.

Berdasarkan dari hasil Gambar di atas, dapat dilihat pada perlakuan A1 memberikan hasil kadar abu yang tertinggi yaitu sebesar 1,97\% sedangkan A2 memberikan hasil kadar abu yang terendah yaitu $1,55 \%$. Hal ini disebabkan karena pada perlakuan A1 lebih banyak mengandung kadar mineral yang cukup tinggi dibandingkan dengan perlakuan A2 dan A3 serta memenuhi syarat mutu kerupuk ikan berdasarkan SNI 2713 1-2009.

Menurut Wiriano (1984), yang menyatakan bahwa semakin tinggi kadar abu pada suatu produk maka semakin tinggi pula kandungan mineral pada produk tersebut sedangkan semakin rendah kadar abu pada suatu produk maka semakin rendah kandungan mineral pada produk tersebut, dan 
dengan tingginya mineral dalam bahan pangan tidak dapat mempengaruhi nilai gizi pada suatu produk.

\subsubsection{Uji Kemekaran Kerupuk dengan perbandingan Ikan Nike dan Ikan Cakalang.}

Hasil analisa rata-rata kemekaran kerupuk ikan nike dan ikan cakalang dari ketiga perlakuan dengan tiga kali ulangan, ditunjukkan oleh Tabel 2 dan Gambar 6 di bawah ini.

Tabel 2. Nilai uji kemekaran.

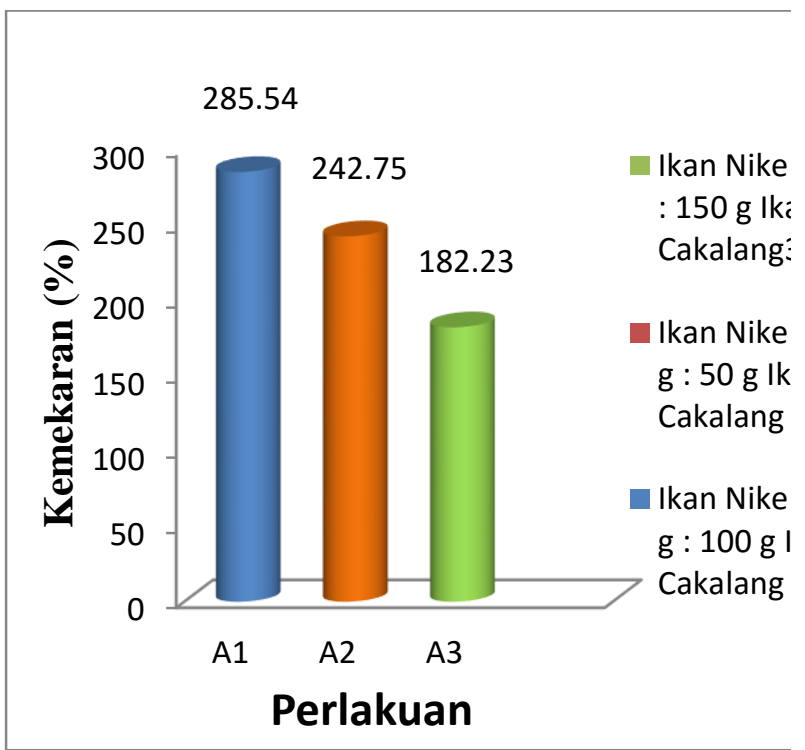

Gambar 6. Rata - rata uji kemekaran kerupuk

Berdasarkan analisis sidik ragam uji kemekaran (Lampiran 7) bahwa F hitung $(1,1)$ lebih kecil dari F tabel $(0,05)$ yaitu 5,14 dan F tabel $(0,01)$ 10,92. Hasil sidik ragam ini menunjukkan bahwa kombinasi antara ikan nike, dan ikan cakalang tidak berpengaruh nyata terhadap kemekaran kerupuk, Sehingga tidak di lakukan uji lanjut BNT. Nilai ratarata kemekaran kerupuk tertinggi adalah terletak pada perlakuan A1 yaitu $285,54 \%$, yang kedua terletak pada perlakuan A2 yaitu 242,75\%, dan yang terendah terletak pada perlakuan A3 yaitu 182,23\%.

$$
\text { Hal ini sesuai dengan pernyataan }
$$

Kusumaningrum (2009), bahwa kandungan amilopektin yang lebih tinggi pada ikan akan memberikan kecenderungan pengembangan kerupuk yang lebih besar dibandingkan dengan amilosa. Amilosa cenderung memicu tinggkat kemekaran kerupuk, sedangkan amilopektin berfungsi sebaliknya mengarah pada pembentukan tekstur yang lebih ringan yang berhubungan langsung dengan kemekaran kerupuk.

Bahan baku kerupuk dengan penambahan ikan nike dan ikan cakalang adalah tepung tapioka. Tepung tapioka ini memiliki kandungan pati yang

\section{Perlakuan Rata-Rata Kemekaran (\%)}

\begin{tabular}{cc}
\hline A1 & 285,54 \\
A2 & 242,75 \\
A3 & 182,23 \\
\hline cukup tinggi. Sumber bahan baku yang digunakan
\end{tabular}

cukup tinggi. Sumber bahan baku yang digunakan untuk membuat kerupuk adalah bahan pangan yang mengandung karbohidrat yang cukup tinggi seperti pati. Pati yang digunakan sebagai bahan baku dalam pembuatan kerupuk di sebut sebagai puffable material. Puffable material adalah bahan yang memegang peranan utama dalam proses pemekaran produk. Granula pati tepung tapioka mempunyai daya pengembangan yang tinggi untuk pengolahan kerupuk. Jadi tepung tapioka merupakan bahan baku kerupuk yang potensial. Tepung tapioka yang telah melalui proses pemanasan yang berulang-ulang kali mengalami pembekakan granula pati sehingga daya ikat terhadap air menurun yang disebabkan pada pori-pori granula pati terbuka sehingga mengakibatkan kemekaran kerupuk pada saat proses penggorengan (Astawan, 2003).

\subsubsection{Uji Tekstur Analizer Kerupuk Ikan Nike dan Ikan Cakalang.}

Menurut Varela et al. (2008) Nilai kerenyahan diukur menggunakan tekstur analisis dengan melihat puncak pertama yang signifikan pada kurva, dan nilai kekerasan dilihat dari puncak 
maksimum pada kurva. Semakin renyah suatu produk maka nilai puncaknya semakin tinggi. Hasil pengukuran dengan tekstur analyzer menunjukkan bahwa nilai kerenyahan berbanding terbalik dengan nilai kekerasan.

Hasil analisa rata-rata uji tekstur analizer dari ketiga perlakuan kerupuk dengan tiga kali ulangan ditunjukkan oleh Tabel 3 dan Gambar 7.

Tabel 3. Nilai uji Tekstur Analizer pada kerupuk ikan nike dan ikan cakalang.

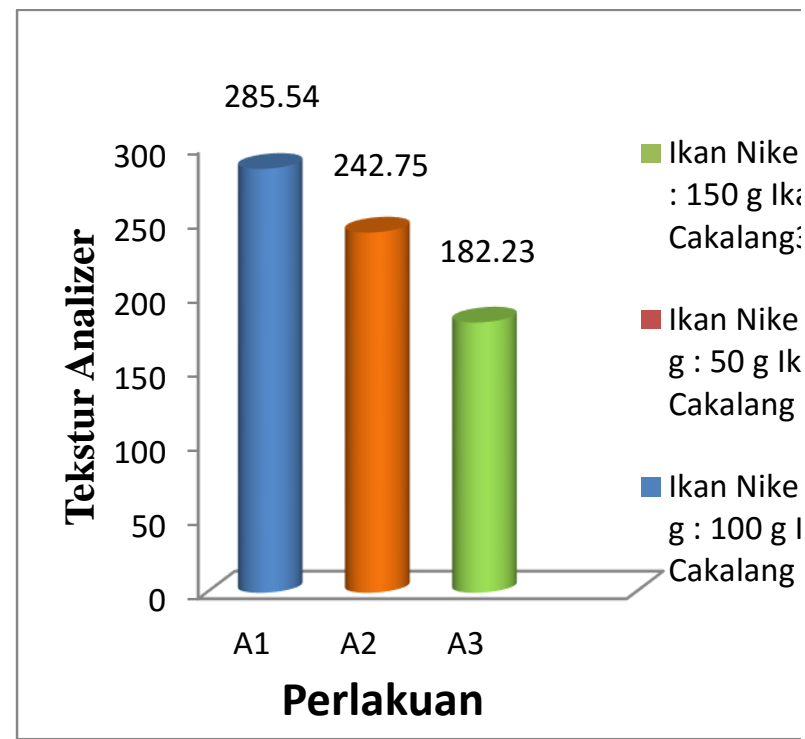

Gambar 7. Rata - rata uji tekstur analizer kerupuk ikan nike dan ikan cakalang.

Berdasarkan analisis sidik ragam tekstur analizer bahwa $\mathrm{F}$ hitung $(1,4)$ lebih kecil dari $\mathrm{F}$ tabel $(0,05)$ yaitu 5,14 dan $\mathrm{F}$ tabel $(0,01)$ yaitu 10,92 . Hasil analisa sidik ragam ini menunjukkan bahwa kombinasi antara ikan nike dan ikan cakalang tidak berpengaruh nyata terhadap tektur analizer kerupuk, sehingga tidak di lakukan uji BNT lagi. Hal ini menunjukkan bahwa tekstur analizer pada masingmasing kerupuk memiliki tekstur yang tingkat kekerasannya renyah. Tekstur merupakan penentu terbesar mutu pangan. Sifat tekstur tergantung pada fisik, ukuran, dan bentuknya. Adapun nilai dari gambar 11 pada ketiga perlakuan menunjukkan nilai A1 (285,54), A2 $(242,75)$, dan A3 $(185,23)$. Nilai yang paling tinggi menurut uji tekstur analizer terletak pada perlakuan A1 yaitu 285,54 dan yang paling rendah terdapat pada perlakuan A3 yaitu 185,23. Hal ini menunjukkan bahwa komposisi didalam Kerupuk dengan penambahan ikan nike dan ikan cakalang tidak berpengaruh terhadap kerenyahannya.

Kerenyahan ini sangat berhubungan dengan pengembangan. Apabila suatu produk semakin mengembang, maka hasilnya akan semakin

Perlakuan Nilai Rata-rata Tekstur Analizer

\begin{tabular}{cc}
\hline A1 & 1185,6 \\
A2 & 708,9 \\
A3 & 783,83
\end{tabular}

renyah. Pada tahap pelapisan ikan dengan tepung, air dalam tubuh ikan ikut terserap, selanjutnya pada proses penggorengan terjadi penguapan air yang disebabkan karena adanya perpindahan panas, secara bersamaan dan terjadilah proses gelatinisasi dan pengembangan, yang dimana tepung pelapis akan mengembang saat pemanasan, butir-butir pati yang ada akan mengembang dan berongga, serta air yang terserap ikut terperangkap pada bahan.

Tekstur merupakan karakteristik utama dari kerupuk dengan penambahan ikan nike dan ikan cakalang. Suhu dan waktu penggorengan merupakan salah satu faktor penting didalam pembuatan kerupuk setelah formulasi dan bahan tambahan yang digunakan.

\section{KESIMPULAN}

Bedasarkan hasil dan pembahasan yang telah dilakukan terhadap mutu kerupuk dengan penambahan ikan nike dan ikan cakalang pada tiga perlakuan maka diperoleh kesimpulan sebagai berikut :

1. Perlakuan yang paling tepat dan disukai oleh panelis adalah perlakuan A1 (tepung tapioka $300 \mathrm{~g}$, ikan nike $100 \mathrm{~g}$, ikan cakalang $100 \mathrm{~g}$ ). 
2. Peningkatan mutu kerupuk dengan penambahan ikan nike dan ikan cakalang memiliki nilai kandungan kimia yang baik yang diantaranya adalah sebagai berikut rata-rata kadar air $(3,30 \%)$, kadar abu $(1,97 \%)$, kemekaran $(285,54 \%)$, dan tekstur analizer $(1185,60)$. Hal ini sudah memenuhi syarat mutu kerupuk ikan berdasarkan SNI 2713.1-2009.

\section{DAFTAR PUSTAKA}

Andarwulan, N., Kusnandar, F. dan Herawati. D. 2011. Analisis Pangan. Dian Rakyat. Jakarta.

Erawati, W.R. 2001. Pengaruh Bahan Pengikat, Waktu Penggorengan dan Daya Simpan Terhadap Sifat Fisik dan Organoleptik Nugget Ikan Sapu-Sapu(Hyposascus Pardalis). Fakultas Ilmu Kelautan Dan Perikanan. Institut Pertanian Bogor, Bogor. Haryadi,H. Syarief R , Santausa S, Isyana S.1989.Teknologi Pengemasan Pangan. PAU Pangan dan Gizi IPB. Bogor.

Intarasirisat, R., S. Benjakul and W. Visessanguan. 2011. Chemical Compositions of The Roes from Skipjack, Tongol and Bonito. Food Chemistry. 124:1328-1334.

Jayanti, A.E. 2009. Pemanfaatan Flavor Kepala Udang Windu (Penaeus Monodon) dalam Pembuatan Kerupuk Berkalsium dari Cangkang Rajungan (Portunus Sp). [Skripsi] Pasca Sarjana Fakultas Perikanan dan Ilmu Kelautan Institut Pertanian Bogor. Bogor.

Kekenusa, S. J., Watung, R.N., Victor dan Djoni, H. 2012. Analisis Penentuan Musim Penangkapan Ikan Cakalang (Katsuwonus pelamis) Di Perairan Manado Sulawesi Utara. Jurnal Ilmiah Sains, 12 (4), 112-113
Ketaren S. 2005. Pengantar Teknologi Minyak dan Lemak Pangan. UI-Press. Jakarta.

Kusumaningrum, I. 2009. Analisa Daya Kembang dan Daya Serap Kerupuk Rumput Laut Pada Variasi Proporsi Rumput Laut ( Eucheuma Cattonii ). Jurnal ISSN 18582419 Vol. 4, No 2.

Panti, M. 2014. Analisa Sifat Kimia Pada Kerupuk Udang Kentang. Program Studi Teknologi Hasil Pertanian. Politeknik Gorontalo.

Muliawan, D. 1991. Pengaruh berbagai Tingkat Kadar Air terhadap Pengembangan Kerupuk sagu Goreng. Skripsi. Jurusan Teknologi Pangan dan Gizi. Fakultas Teknologi Pertanian IPB. Bogor.

Palungkun, R dan Budiarti, A. 1992. Bawang Putih Dataran Rendah. Penebar Swadaya. Jakarta Pastiniasih. 2011. Menguji Organoleptik. Bagian Proyek Pengembangan Kurikulum Direktorat jendral Pendidikan Dasar dan Menengah Departemen Pendidikan Nasional. Jakarta.

Peleg M \& EB Bagley. 1983. Physical Properties of Food. Connecticut: AVi Publishing Company, Inc.

Priwindo, S. 2009. Pengaruh Pemberian Bawang Putih Terhadap Kualitas Kerupuk. Skripsi. Departemen Perikanan. Fakultas Pertanian. Medan : Universitas Sumatera Utara

Standar Nasional Indonesia. 1999. Kerupuk Ikan 2713.1-1999. Departemen Perindustrian. Jakarta.

Tababaka T. 2004. Pemanfaatan tepung tulang ikan patin (Pangasius sp.) sebagai bahan tambahan kerupuk. [skripsi]. Fakultas Perikanan dan Ilmu Kelautan. Institut Pertanian Bogor. Bogor. 
Tantu, F. 2001. Kelimpahan Spasial-Temporal Nike

(Ordo Gobioidea) Di Muara Sungai Bone

Gorontalo [Tesis]. Program Pasca Sarjana,

Universitas Sam Ratulangi Manado.

Manado.

Varela P, Salvador A, Fiszman. 2008

Menthodological developments in

Crispiness assessment : Effects of Cooking

On The crispness Of Crusted Foods. Jurnal

Of Food Science and Technology 41 :

1252-1259.

Wahyono, R dan Marzuki. 1996. Pembuatan Aneka

Kerupuk. Penerbit Trubus Agrisana.

Malang.

Winarno, F.G.2002. Flavor Bagi Industri Pangan.

Embrio Press. Bogor.

Winarno, F.G. 2008. Bahan Tambahan Makanan.

Gramedia, Jakarta.

Wiriano H. 1984. Mekanisme Teknologi Pembuatan

Kerupuk. Balai Penelitian dan

Pengembangan Industri, Balai

Pengembangan Makanan Fitokimia,

Jakarta: Departemen Perindustrian.

Yamasaki N. dan Tachihara K. 2006. Enggs and larvae of Awaous melanocephalus (Teleostei: Gobiidae). J Ichtyol Res 54: 8991

Yusuf, N. 2011. Karakterisasi Gizi Dan Pendugaan Umur Simpan Savory Chips Ikan Nike (Awaous Melanocephalus). Tesis. Sekolah Pasca sarjana Institut Pertanian Bogor. Bogor. 